W. Hasegawa, Y. Watanabe, H. Matsuoka, S. Ohsawa, B. Brahmantyo, K.A. Maryunani, and T. Tagami. Environmental parameters controlling stalagmite growth in tropical areas: New insights from cave monitoring at Petruk Cave, central Java, Indonesia. Journal of Cave and Karst Studies, v. 80, no. 1, p. 19-27. DOI: 10.4311/2015LSC0118R3

\title{
ENVIRONMENTAL PARAMETERS CONTROLLING STALAGMITE GROWTH IN TROPICAL AREAS: NEW INSIGHTS FROM CAVE MONITORING AT PETRUK CAVE, CENTRAL JAVA, INDONESIA
}

\author{
Wataru Hasegawa1, Yumiko Watanabe ${ }^{1, c}$, Hiroshige Matsuoka1, Shinji Ohsawa², \\ Budi Brahmantyo ${ }^{3}$, Khoiril Anwar Maryunani ${ }^{3}$, and Takahiro Tagami ${ }^{1}$
}

\section{Abstract}

To elucidate environmental parameters controlling stalagmite growth in tropical areas, we conducted cave monitoring throughout a year in Petruk Cave, central Java, Indonesia. We compared stalagmite growth rate with the cave's environmental parameters, air temperature, drip rate, calcium concentration of the drip waters, and $p \mathrm{CO}_{2}$-air. We found a relationship where stalagmite growth rate is fast (slow) when $\mathrm{pCO}_{2}$-air is low (high) during dry (rainy) season, suggesting that $p \mathrm{CO}_{2}$-air controls stalagmite growth. Note that this is a first study that reports that dramatic $p \mathrm{CO}_{2}$-air reduction occurring during dry season in a tropical cave controls stalagmite growth. Additionally, we discuss the mechanism of $p \mathrm{CO}_{2}$-air fluctuation. Monitoring results show that $\mathrm{pCO}_{2}$-air fluctuation is divided into two phenomena: seasonal fluctuations and daily fluctuations. Dramatic $\mathrm{pCO}_{2}$-air reduction during the dry season is likely to result from a decline of plant activity due to little rainfall. On the daily scale, $\mathrm{pCO}_{2}$-air reached to the minimum around 6 a.m. and maximum around 2-4 p.m., although it is not obvious whether this is due to plant activity or cave ventilation. Also, dynamic $p \mathrm{CO}_{2}-$ air reduction was observed following cave ventilation driven by the sudden drop of outside air temperature due to a downburst during severe rain. This suggests that heavy rainfall in short duration is also one factor that controls cave ventilation and $\mathrm{pCO}_{2}$-air.

\section{Introduction}

Stalagmite geochemistry has been widely recognized as a useful proxy to reconstruct paleoclimate or paleoenvironment of terrestrial areas (e.g., Wang et al., 2001; Fairchild et al., 2006; Wang et al., 2008). If stalagmite growth rate has a seasonal variation, the geochemical signatures might be influenced as well by the seasonal variation in growth rate. Meanwhile, some previous studies have utilized stalagmite growth-rate itself as a paleoclimate or environment proxy (e.g., Proctor et al., 2000; regional precipitation reflecting the strength of the winter North Atlantic Oscillation; Polyak and Asmerom, 2001, wet/dry condition). It is, therefore, important to elucidate the mechanism of stalagmite growth for reconstructing paleoclimate or environment using stalagmites.

Recently, cave monitoring studies were conducted to understand the relationships between surface climate and stalagmite characteristics (e.g., Spötl et al., 2005; Banner et al, 2007; Baldini et al., 2008; Mattey et al., 2010; Boch et al., 2011; Tremaine et al., 2011). Previous studies from the mid-latitudes revealed that stalagmite growth rate is affected by several factors, such as air temperature, drip rate, calcium ion concentration, which is given as [ $\left.\mathrm{Ca}^{2+}\right]$ in this study (e.g., Baker et al., 1998; Genty et al., 2001), or partial pressure of cave air $\mathrm{CO}_{2}$, which is given as $p \mathrm{CO}_{2}$-air in this study (e.g., Spötl et al., 2005; Banner et al, 2007; Baldini et al., 2008). Especially, Banner and his colleagues conducted cave monitoring in central Texas, USA, and discussed seasonal variations of stalagmite growth. Banner et al. (2007) reported that the stalagmite growth rate inversely correlated to seasonal changes in outside air temperature, with nearly no growth rates during the warmest summer months and high growth rates from fall to spring, suggesting that the seasonal variations of stalagmite growth rates were primarily controlled by regional air temperature effects on ventilation of cave-air $\mathrm{CO}_{2}$ concentrations or drip water $\mathrm{CO}_{2}$ contents. At the study site of Banner et al. (2007), outside air temperatures have a large seasonal variation, ranging from 0 to $30^{\circ} \mathrm{C}$. In contrast, outside air temperature at our study site, central Java, Indonesia, is almost constant through the year, and precipitation has a distinctive seasonal cycle of wet and dry seasons.

Cave monitoring studies are very limited in the tropics, except small numbers of studies in such as Belize (Ridley et al., 2015) and Brazil (Sondag et al., 2003). Sondag et al. (2003) presents monitoring data for temperature, atmospheric pressure, and drip rate in two caves of Brazil. Also, Ridley et al. (2015) presented the results of cave monitoring in Yok Balum Cave, Belize, where outside temperature has a small seasonal variation, ranging from 21 to $24{ }^{\circ} \mathrm{C}$. Their evidence shows that clear seasonal ventilation regimes exist, driven by thermally induced inside-outside air density differences (Ridley et al., 2015). The winter (summer) regime is dominated by air inflow (outflow), low (high) $p \mathrm{CO}_{2}$-air, and lower (higher) epikarstic drawdown (Ridley et al., 2015). However, on previous studies of tropical cave monitoring,

\footnotetext{
'Division of Earth and Planetary Sciences, Graduate School of Science, Kyoto University, Kyoto 606-8502, Japan

${ }^{2}$ Institute for Geothermal Sciences, Graduate School of Science, Kyoto University, Noguchibaru, Beppu 874-0903, Japan

${ }^{3}$ Faculty of Earth Sciences and Mineral Technology, Institut Teknologi Bandung, Jl. Ganesa 10, Bandung 40132, Indonesia

cCorresponding author: yumiko@kueps.kyoto-u.ac.jp
} 
Ridley and his colleagues had no robust evidence of the relationship between stalagmite growth and surface climate. In this study, to elucidate environmental parameters controlling stalagmite growth rate in tropical area, cave monitoring was conducted throughout a year in Petruk Cave, central Java, Indonesia. We monitored stalagmite growth rate and environmental parameters of relative humidity, air temperature, drip rate, $\left[\mathrm{Ca}^{2+}\right]$, and $\mathrm{CCO}_{2}$-air. Results of this study are a significant first step to reconstruct paleoclimate or environment precisely using stalagmites in a tropical area, especially in regions characterized by constant outside air temperature through the year and a seasonal rainfall pattern.

\section{Study Area}

Cave monitoring was conducted in Petruk Cave, central Java, Indonesia. The cave is located on the western side of Karangbolong karst area, and the total length of the cave is about $350 \mathrm{~m}$ (Fig. 1). The elevation of the main entrance is about $80 \mathrm{~m}$ a.s.l., and a river flows along the main corridor of the cave. Limestone bedrock overburden of the cave is approximately $70 \mathrm{~m}$ above the entrance and $120 \mathrm{~m}$ above the center of the cave (Fig. 1c).

The climate diagram of Jogjakarta city, which is located about $100 \mathrm{~km}$ east from Petruk Cave, is shown in Figure. 2. At the study site, the monthly mean temperature is almost constant throughout the year, and precipitation has a seasonal cycle, with the dry season from May to October and the wet season from November to April (Fig. 2), in conjunction with movement of the Intertropical Convergence Zone.

\section{Monitoring Method}

Monitoring was conducted at seven stations in the cave (P1-2, P1-river, P2, P3-1, P3-2, P3-river, and P4) and a station outside the cave (Fig. 1). The surface station is located $200 \mathrm{~m}$ away from the main entrance and at an elevation of 0 $\mathrm{m}$ a.s.I.. P1-2 is located on the cave river terrace that is about $50 \mathrm{~m}$ away from the main entrance and about $4 \mathrm{~m}$ above the cave floor. P1-river is located at the stream bank of the cave river near P1-2. P2 is located at the narrow corridor with a climb up the stairs from the large hall (approximately $30 \mathrm{~m}$ width, $70 \mathrm{~m}$ length, and $30 \mathrm{~m}$ height), which is about $150 \mathrm{~m}$ away from the entrance, and the relative elevation to the cave river is about $30 \mathrm{~m}$. P3-1 and P3-2 are adjacent stations (approximately $3 \mathrm{~m}$ distance), and both stations are located on the cave river terrace on the east side of the large hall. P3-river is located at the stream bank of the river near P3-1 and P3-2. P4 is located $30 \mathrm{~m}$ away from the large hall and about $4 \mathrm{~m}$ above the river. An open corridor runs from the entrance to P1-2, P1-river, P3-1, P3-2, and P4, whereas P2 is located in a relatively closed part of the cave (Fig. $1 \mathrm{~b}$ and c).

In this study, stalagmite growth rate and environmental parameters were monitored in Petruk Cave from October 2011 to December 2012. Environmental parameters that were monitored are relative humidity, air temperature in the cave and outside, cave airflow direction, wind speed, $\mathrm{pCO}_{2}$-air, drip rate, precipitation, and chemical compositions of

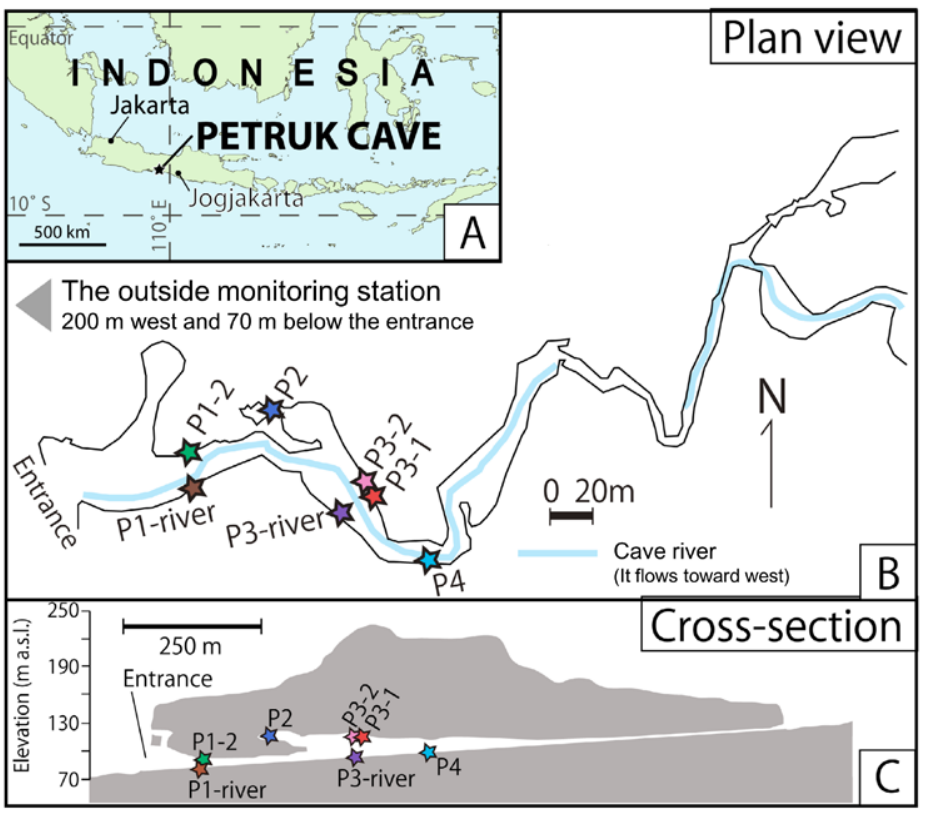

Figure 1. Location and monitoring station map of Petruk Cave. It is modified from cave map of Brahamantyo et al. (2006). (A) The location of the cave. (B) Plan view of the cave. The stars present monitoring stations inside the cave, and the outside monitoring station is $200 \mathrm{~m}$ west and $70 \mathrm{~m}$ below the entrance. (C) Cross-section of the cave. drip water (i.e., $\mathrm{Ca}^{2+}, \mathrm{HCO}_{3}^{-}, \mathrm{Na}^{+}, \mathrm{Mg}^{2+}, \mathrm{Cl}^{-}, \mathrm{NO}_{3}^{-}$and $\mathrm{SO}_{4}^{2-}$ ).

Monitoring parameters and stations are summarized in Table 1 and Figure 1. Air temperature, airflow, and pCO2-air were measured at all cave stations. Relative humidity was measured at P1-2, P1-river, P3, and outside. Drip water sampling and the measurement of stalagmite growth rate were conducted at four stations (P1-2, P2, P3-1, and P3-2) and three stations (P1-2, $\mathrm{P} 3-1$, and P3-2), respectively.

Precipitation, drip rate, air temperature, and relative humidity were logged with Onset $\mathrm{HOBO}$ micro Station Logger (H21-002) in 15 to 20 minute intervals. Precipitation and drip rate were measured with tipping-bucket rain gauges (Onset S-RGB-M002). Air temperature and relative humidity were measured with air temperature and relative humidity smart sensors (Onset $U$ DTW-1).

$\mathrm{pCO}_{2}$-air was measured and logged continuously with Sense Air A/N074001 $\mathrm{CO}_{2}$ gauges in 20 minute intervals. Airflow direction was measured with incense sticks, and wind speed measured with Testo 425 hotwire anemometer. Water temperature and $\mathrm{pH}$ were measured in situ with a HORIBA D-54 pH gauge.

Drip water was collected into $10.4 \mathrm{ml}$ or $4.9 \mathrm{ml}$ tubes 
Table 1. Cave monitoring parameters and stations.

\begin{tabular}{|c|c|c|c|c|c|c|c|c|c|c|c|c|}
\hline \multirow[b]{2}{*}{$\begin{array}{l}\text { Station } \\
\text { Name }\end{array}$} & \multirow[b]{2}{*}{ Precip. } & \multicolumn{4}{|c|}{ Air } & \multicolumn{6}{|c|}{ Drip Water } & \multirow[b]{2}{*}{$\begin{array}{l}\text { Speleothem } \\
\text { Growth Rate }\end{array}$} \\
\hline & & Temp. & $\begin{array}{l}\text { Relative } \\
\text { Humidity }\end{array}$ & $\begin{array}{c}\mathrm{pCO}_{2}= \\
\text { air }\end{array}$ & $\begin{array}{c}\text { Air-Flow } \\
\text { Direction } \\
\text { and Speed }\end{array}$ & $\begin{array}{l}\text { Drip } \\
\text { Rate }\end{array}$ & $\begin{array}{c}\text { Chemical } \\
\text { Composition }^{a}\end{array}$ & $\mathrm{pH}$ & $\begin{array}{c}\text { Water } \\
\text { Temperature }\end{array}$ & $\begin{array}{c}\mathrm{pCO}_{2}- \\
\text { drip }\end{array}$ & $\mathrm{SI}_{\mathrm{cc}}$ & \\
\hline Outside & $\mathrm{L}$ & $L$ & L & $\cdots$ & $\cdots$ & $\cdots$ & $\cdots$ & $\cdots$ & $\cdots$ & $\cdots$ & $\cdots$ & $\cdots$ \\
\hline Entrance & $\cdots$ & $\cdots$ & $\cdots$ & $\cdots$ & M & $\cdots$ & $\cdots$ & $\cdots$ & $\cdots$ & $\cdots$ & $\cdots$ & $\cdots$ \\
\hline P1-2 & $\cdots$ & $\mathrm{L}$ & L & Ls & $\mathrm{M}$ & $\mathrm{L}$ & $S$ & M & M & $\mathrm{C}$ & C & $S$ \\
\hline P1-River & $\cdots$ & $\mathrm{L}$ & L & Ls & $\mathrm{M}$ & $\ldots$ & $\ldots$ & $\ldots$ & $\ldots$ & $\ldots$ & $\ldots$ & $\ldots$ \\
\hline P2 & $\cdots$ & Ls & $\cdots$ & Ls & $\mathrm{M}$ & $\cdots$ & $S$ & M & M & $\mathrm{C}$ & $\mathrm{C}$ & $\cdots$ \\
\hline P3-1 & $\cdots$ & L (P3) & L (P3) & Ls (P3) & $\mathrm{M}(\mathrm{P} 3)$ & $\mathrm{L}$ & $S$ & $M$ & M & C & $\mathrm{C}$ & $\mathrm{S}$ \\
\hline P3-2 & $\cdots$ & L (P3) & L (P3) & Ls (P3) & M (P3) & $\mathrm{L}$ & $S$ & M & M & $\mathrm{C}$ & C & $S$ \\
\hline P3-River & $\cdots$ & Ls & $\ldots$ & Ls & $\mathrm{M}$ & $\cdots$ & $\cdots$ & $\cdots$ & $\cdots$ & $\cdots$ & $\cdots$ & $\cdots$ \\
\hline P4 & $\cdots$ & Ls & $\ldots$ & Ls & $\mathrm{M}$ & $\cdots$ & $\cdots$ & $\cdots$ & $\cdots$ & $\cdots$ & $\cdots$ & $\cdots$ \\
\hline
\end{tabular}

a Measured drip water chemical composition $=$ (i.e., $\mathrm{Ca}^{2+}, \mathrm{HCO}_{3}{ }^{-}, \mathrm{Na}^{+}, \mathrm{Mg}^{2+}, \mathrm{Cl}^{-}, \mathrm{NO}_{3}{ }^{-}$, and $\mathrm{SO}_{4}{ }^{2-}$ ).

Notes:

$\mathrm{C}=$ Calculated by other data.

$\mathrm{L}=$ Continuous logging.

$\mathrm{Ls}=\mathrm{A}$ few days continuous logging in each season.

$M=$ Manual measurement in each season.

$\mathrm{S}=$ Sampling and laboratory measurement.

and sealed with silicon plugs. Major ion compositions of drip water (i.e., $\mathrm{Ca}^{2+}, \mathrm{Na}^{+}, \mathrm{Mg}^{2+}, \mathrm{Cl}^{-}, \mathrm{NO}_{3}^{-}$and $\mathrm{SO}_{4}^{2-}$ ) were determined by ion chromatography (DIONEX ICS-1100). Bicarbonate ion $\left[\mathrm{HCO}_{3}^{-}\right]$was determined by the spectrophotometric method according to Mishima et al. (2009). The saturation index of calcite $\left(\mathrm{SI}_{\mathrm{cc}}\right)$ is defined as follows:

$$
\mathrm{SI}_{\mathrm{CC}}=\frac{\log \left[\mathrm{Ca}^{2+}\right] \times\left[\mathrm{CO}_{3}^{2-}\right]}{K_{C}}=\log \frac{K_{2} \times\left[\mathrm{Ca}^{2+}\right] \times\left[\mathrm{HCO}_{3}^{-}\right]}{K_{C} \times\left[\mathrm{H}^{+}\right]}
$$

$\mathrm{K}_{\mathrm{c}}$ and $\mathrm{K}_{2}$ are respectively the equilibrium constants for the reactions $\mathrm{Ca}^{2+}+\mathrm{CO}_{3}{ }^{2-} \leftrightarrow \mathrm{CaCO}_{3}$ and $\mathrm{HCO}_{3}{ }^{-} \leftrightarrow \mathrm{H}^{+}$ $+\mathrm{CO}_{3}{ }^{2-} \cdot \mathrm{K}_{\mathrm{c}}$ and $\mathrm{K}_{2}$ are determined by drip-water temperature.

Stalagmite growth rate was measured by a stalagmite-farming experiment at three stations (i.e., P1-2, P3-1, and P32; Fig. 1; Table 1). A sandblasted glass plate was installed horizontally, and then the glass plate was weighted before and after the stalagmite farming to estimate stalagmite growth rate.

\section{Results}

\section{Relative Humidity, Air Temperature, Drip Rate, and Precipitation}

Monitoring results of relative humidity, air temperature, drip rate, and precipitation are shown in Figure 3. Outside relative humidity varied from 43 to $100 \%$, and the daily average was 75 to $95 \%$ (Fig. 3a). Outside relative humidity of the dry season was about $10 \%$ less than that of the rainy season. At P1-2, relative humidity was from 90 to $100 \%$

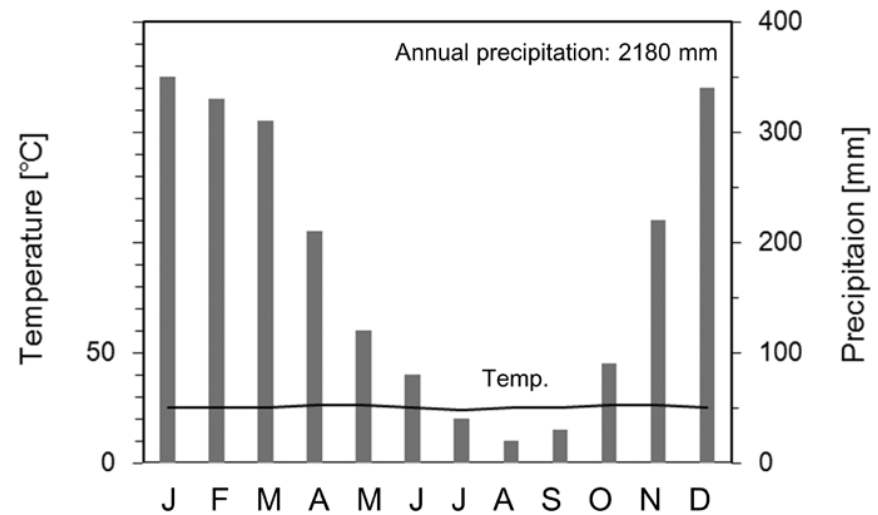

Figure 2. The climate of Jogjakarta city, which is located about $100 \mathrm{~km}$ east from Petruk Cave. The climate data are from http:// www.weatherbase.com. The monthly means of air temperature are almost constant throughout a year. Annual precipitation is about $2180 \mathrm{~mm}$, and there is a seasonal cycle with a dry season from May to October and a wet season from November to April. throughout the year and the daily range was little (1 to $3 \%$ ). Relative humidity during the early dry season (May to July) was 3 to $5 \%$ less than the other season. At P31 , relative humidity was almost $100 \%$, and there were no variations on both daily and seasonal scale.

Although outside air temperature fluctuated from 21.8 to $34.5^{\circ} \mathrm{C}$, the daily average was 25 to $29^{\circ} \mathrm{C}$ throughout the year and there was no seasonal variation (Fig. 3a). At $\mathrm{P} 1-2$ and $\mathrm{P} 1$-river, air temperature varied from 23 to $27^{\circ} \mathrm{C}$ and daily range was less than $2{ }^{\circ} \mathrm{C}$. At P3-1, air temperature varied from 26.7 to $27.3^{\circ} \mathrm{C}$ and there was no fluctuation on both daily and seasonal scale.

The drip-rate varied from 0.042 to $0.061 \mathrm{ml} \mathrm{s}^{-1}$ at P1-2, from 0.058 to $0.068 \mathrm{ml} \mathrm{s}^{-1}$ at P3-1, and from 0.007 to 0.018 $\mathrm{ml} \mathrm{s}^{-1}$ at P3-2, respectively (Fig. 3b). On each station, driprate was almost constant throughout a year and had no response to heavy rainfall (Fig. 3b). 


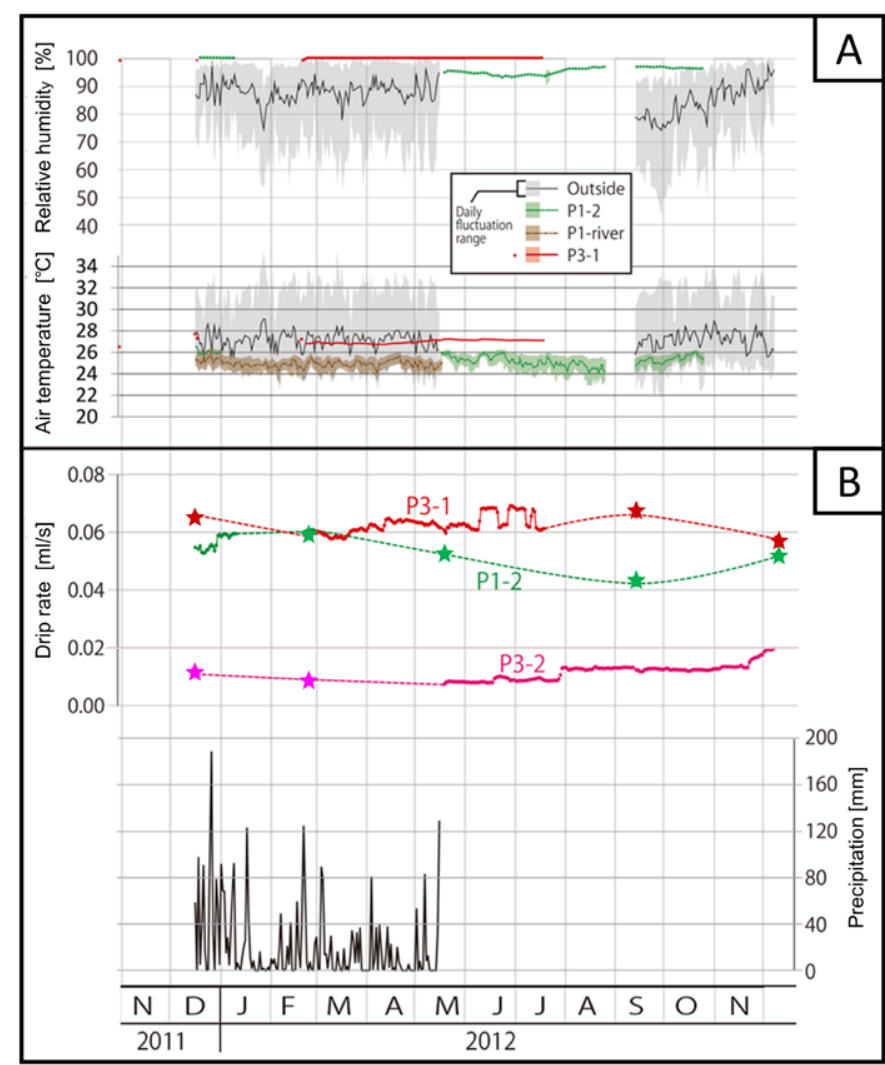

Figure 3. (Top) Temporal variations of relative humidity and air temperature. Shaded bands indicate daily fluctuation range. Relative humidity inside the cave (i.e., P3-1) is almost $100 \%$ and there was no variation on both daily and seasonal scale. Air temperature inside the cave (i.e., P3-1) is also constant. (Bottom) Temporal variations of drip rate and precipitation. Solid lines indicate the results of continuous monitoring and the dashed lines represent interpolated trend of "snap-shot" data measured manually.

\section{Cave Ventilation and $\mathrm{pCO}_{2}$-air \\ Cave ventilation}

The monitoring results for cave airflow are shown in Figure 4. Airflow speed at the entrance is higher than that of cave inside. No airflow was sometimes observed at P2 and P3, which are located at the upper part of the cave. Throughout a year, cave air almost always flows toward the entrance, except at P1-river, where it usually flows inward.

\section{Seasonal fluctuation of $\mathrm{pCO}_{2}$-air}

The seasonal fluctuation of $p \mathrm{CO}_{2}$-air is shown in Figure 5. In May 2012, September 2012, and December 2012, continuous monitoring was conducted during a few days each month. In February 2012, long continuous monitoring was not conducted, but snapshot $p \mathrm{CO}_{2}$-air measurements were conducted by manual measurements. Results of the snapshot measurement were approximately 400 to $1700 \mathrm{ppm}$ at $\mathrm{P} 1-2$, approximately 1400 to $2100 \mathrm{ppm}$ at $\mathrm{P} 2$, approximately 1600 to 2400 ppm at P3-1, and approximately 2100 to 2500 ppm at P4, respectively. It is thought that the snapshot data are biased for daytime because the measurements were conducted in-situ only from 10 a.m. to 4 p.m.

In September 2012, $\mathrm{pCO}_{2}$-air was dramatically lower than other seasons, and daily range was also low at all stations inside cave (Fig. 5). In contrast, in May 2012 and December 2012, $p \mathrm{CO}_{2}$-air was higher and daily fluctuating range was also higher (Fig. 5).

Daily fluctuation of $\mathrm{pCO}_{2}$-air

Daily $p \mathrm{CO}_{2}$-air variations are shown in Figures 6 and 7. Figure 6 is continuous-monitoring data during 3 days or 4 days in May 2012, September 2012, and December 2012. In Figure 7 are the data of February 2012, when we conducted continuous monitoring during only 6 hours or 10 hours. Throughout the year, outside air temperature reached to the minimum around 6 a.m. and a maximum around 1 p.m. (Fig. 6; Fig. 7), whereas air temperature inside the cave stays constant (approximately $27^{\circ} \mathrm{C}$ ). $p \mathrm{CO}_{2}$-air reached a minimum around 6 a.m. and a maximum around 2 to 4 p.m. (Fig. 6; Fig. 7). 


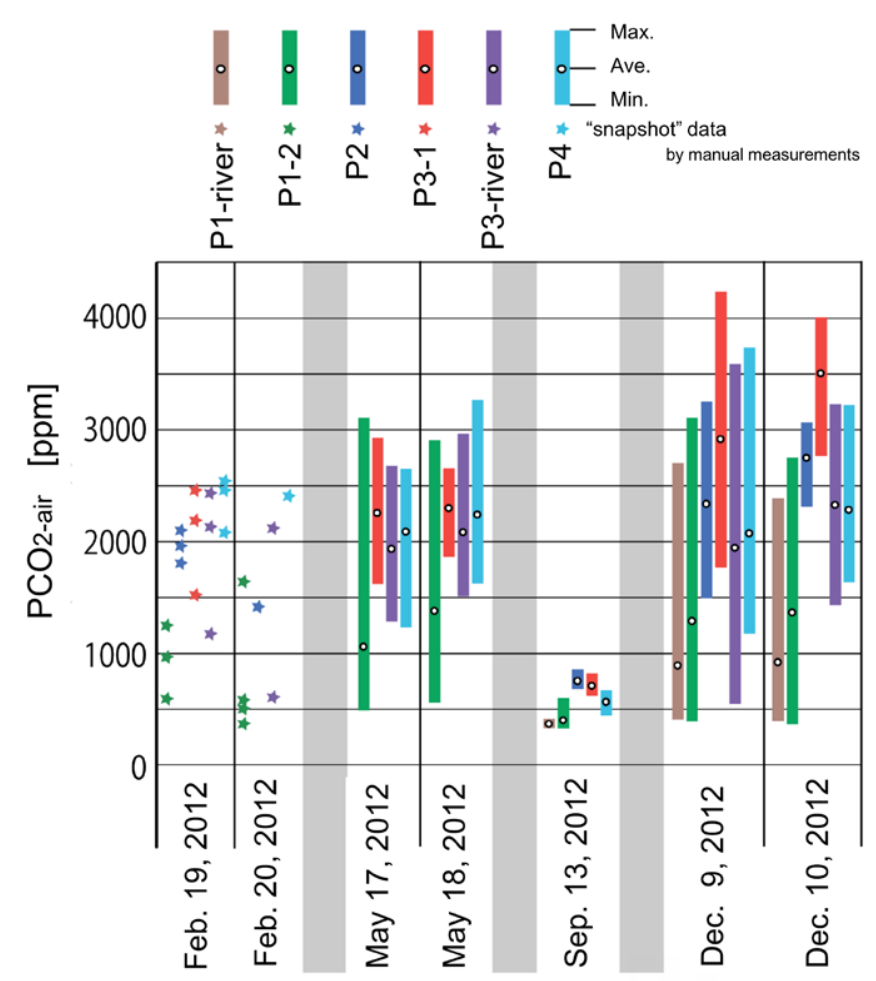

Figure 5. Seasonal fluctuation of $\mathrm{pCO}_{2}$-air. The circles present daily average and bars present daily fluctuation based on the results of continuous monitoring. Stars indicate the snap-shot data measured by manual observation. Note that $\mathrm{CCO}_{2}$-air in the dry season (i.e., September- 2012) was very low and the daily fluctuations small.

\section{Chemical Composition of Drip Water}

Chemical data of drip water are summarized in Table 2, and some data are graphed in Figure 8. Obvious seasonal variations on all data of drip water were regarded as unlikely (Table 2; Fig. 8).

Because there was no daily fluctuation data of $\mathrm{pCO}_{2}-$ air in December 2011 and February 2012, we chiefly describe seasonal variation of drip water based on the data of May 2012, September 2012, and December 2012. [ $\left.\mathrm{Ca}^{2+}\right]$ and $\left[\mathrm{HCO}_{3}^{-}\right]$of September 2012 appear to be lower than those of other seasons (i.e., May 2012 and December 2012), and [Mg/Ca] ratio of September 2012 is slightly higher than that of other seasons (Fig. 8). The evidence that the $[\mathrm{Mg} / \mathrm{Ca}]$ ratio becomes higher during lower $p \mathrm{CO}_{2}$-air resembles results of previous researches (e.g., Mattey et al. 2010; Wong et al., 2011), showing that the amount of prior calcite precipitation (Fairchild et al., 2000) increases during dry season due to low $\mathrm{pCO}_{2}$-air (Fig. 5). However, there is no definitive seasonal variations of $\mathrm{pH}$, saturation index $\left(\mathrm{SI}_{c c}\right.$ ) and $\mathrm{pCO}_{2}$-drip (Fig. 8), as shown in previous studies (e.g., Spötl et al., 2005; Boch et al., 2011), implying that prior calcite precipitation has a small influence on drip water geochemistry in this cave.

\section{Stalagmite Growth Rate}

During the stalagmite farming experiment, donut-shaped stalagmite was formed on the glass plate. Figure 9 presents stalagmite growth rates on the glass plate. The growth rates during the dry season (i.e., May 2012 to September 2012) were 2 to $5 \mathrm{mg} \mathrm{day}^{-1}$ and those in the rainy season were less than $1.8 \mathrm{mg}$ day ${ }^{-1}$. The growth rates of dry season were higher than those of rainy season.

\section{Discussion}

\section{Environmental Parameters Controlling Stalagmite Growth}

According to previous cave-monitoring studies, stalagmite growth was affected by air temperature, drip rate, and [Ca ${ }^{2+}$ (e.g., Baker et al., 1998; Genty et al., 2001) or $\mathrm{pCO}_{2}$-air (e.g., Spötl et al., 2005; Banner et al, 2007; Baldini et al., 2008). Herein we discuss environmental parameters controlling stalagmite growth rate based on the monitoring results of Petruk Cave. 
Table 2. Chemical compositions of drip water samples.

\begin{tabular}{|c|c|c|c|c|c|c|c|c|c|c|c|c|c|c|c|}
\hline $\begin{array}{c}\text { Sample } \\
\text { Location }\end{array}$ & $\begin{array}{c}\text { Date } \\
\text { (mmddyy) }\end{array}$ & Time & $\begin{array}{c}\text { Temp. } \\
\left({ }^{\circ} \mathrm{C}\right)\end{array}$ & $\mathrm{pH}$ & $\begin{array}{l}\text { Drip Rate } \\
\text { (mL/s) }\end{array}$ & $\begin{array}{c}\mathrm{pCO}_{2^{-}} \\
\text {air } \\
(\mathrm{ppm})\end{array}$ & $\begin{array}{c}\mathrm{Na}^{+} \\
(\mathrm{mmol} / \\
\mathrm{L})\end{array}$ & $\begin{array}{c}\mathrm{Mg}^{2+} \\
(\mathrm{mmol} / \\
\mathrm{L})\end{array}$ & $\begin{array}{c}\mathrm{Ca}^{2+} \\
(\mathrm{mmol} / \\
\mathrm{L})\end{array}$ & $\begin{array}{c}\mathrm{Cl}^{-} \\
\text {(mmol/ } \\
\text { L) }\end{array}$ & $\begin{array}{c}\mathrm{NO}_{3}^{-} \\
\text {(mmol/ } \\
\text { L) }\end{array}$ & $\begin{array}{c}\mathrm{SO}_{4}{ }^{2-} \\
\text { (mmol/ } \\
\text { L) }\end{array}$ & $\begin{array}{c}\mathrm{HCO}_{3}^{-} \\
\text {(mmol/ } \\
\text { L) }\end{array}$ & $\begin{array}{l}\mathrm{pCO}_{2-}^{-} \\
\text {drip } \\
(\mathrm{ppm})\end{array}$ & $\mathrm{SI}_{\mathrm{cc}}$ \\
\hline P1-2 & 121611 & $\ldots$ & 26.5 & 7.9 & 0.055 & 870 & 0.113 & 0.029 & 1.669 & 0.062 & 0.849 & 0.012 & 2.496 & 1833 & 0.565 \\
\hline P1-2 & 21912 & $11: 23$ & 26.1 & 7.76 & 0.0583 & 633 & 0.111 & 0.028 & 1.426 & 0.071 & 0.553 & 0.014 & 2.342 & 2378 & 0.331 \\
\hline P1-2 & 51612 & $12: 11$ & 26.3 & 7.8 & 0.0533 & 1061 & 0.129 & 0.031 & 1.645 & 0.07 & 1.293 & 0.014 & 2.08 & 1925 & 0.38 \\
\hline $\mathrm{P} 1-2$ & 51812 & $6: 26$ & 26 & 7.7 & 0.0557 & 751 & 0.11 & 0.03 & 1.63 & 0.08 & 1.22 & 0.014 & 2.231 & 2585 & 0.302 \\
\hline P1-2 & 51812 & $8: 32$ & 26.1 & 7.73 & $\ldots$ & 613 & 0.108 & 0.03 & 1.639 & 0.068 & 1.133 & 0.014 & 2.268 & 2454 & 0.342 \\
\hline P1-2 & 91312 & $8: 28$ & 25 & 7.98 & 0.0426 & 433 & 0.172 & 0.027 & 1.282 & 0.082 & 0.523 & 0.013 & 2.123 & 1286 & 0.452 \\
\hline P1-2 & 91312 & $12: 18$ & 25.3 & 7.87 & 0.043 & 599 & 0.108 & 0.026 & 1.33 & 0.057 & 0.514 & 0.012 & 2.198 & 1718 & 0.375 \\
\hline P1-2 & 91312 & $13: 45$ & 25.3 & 7.9 & 0.0471 & 423 & 0.11 & 0.026 & 1.328 & 0.058 & 0.513 & 0.012 & 2.212 & 1614 & 0.407 \\
\hline $\mathrm{P} 1-2$ & 120912 & $8: 16$ & 26.4 & 7.83 & 0.0516 & 436 & 0.12 & 0.029 & 1.65 & 0.066 & 0.997 & 0.012 & 2.133 & 1843 & 0.423 \\
\hline P1-2 & 121012 & $12: 37$ & 26.1 & 7.91 & 0.0533 & 924 & 0.114 & 0.029 & 1.624 & 0.07 & 1.075 & 0.011 & 2.177 & 1558 & 0.501 \\
\hline P2 & 121611 & $\ldots$ & 27 & 7.9 & 0.0153 & 2550 & 0.178 & 0.033 & 1.324 & 0.098 & 0.215 & 0.012 & 2.542 & 1899 & 0.488 \\
\hline P2 & 22012 & $10: 42$ & 27 & 8.01 & 0.0234 & 1592 & 0.124 & 0.037 & 1.043 & 0.07 & 0.124 & 0.014 & 2.022 & 1188 & 0.407 \\
\hline P2 & 51712 & 11:17 & 27.1 & 8.02 & 0.0126 & 1875 & 0.176 & 0.038 & 1.236 & 0.111 & 0.074 & 0.012 & 2.494 & 1420 & 0.574 \\
\hline P2 & 91312 & $13: 14$ & 28.3 & 7.87 & 0.0094 & 856 & 0.114 & 0.031 & 0.922 & 0.068 & 0.111 & 0.012 & 1.829 & 1523 & 0.194 \\
\hline P2 & 120912 & $13: 42$ & 27.3 & 8.02 & $\ldots$ & 1719 & 0.121 & 0.034 & 1.321 & 0.059 & 0.413 & 0.011 & 2.14 & 1223 & 0.54 \\
\hline P3-1 & 121511 & $\ldots$ & 27.7 & 7.6 & 0.0661 & 2618 & 0.137 & 0.036 & 1.595 & 0.062 & 0.528 & 0.014 & 2.681 & 4006 & 0.294 \\
\hline P3-1 & 121611 & $\ldots$ & 27.3 & 7.9 & 0.0598 & 1963 & 0.138 & 0.036 & 1.592 & 0.06 & 0.493 & 0.014 & 2.628 & 1957 & 0.58 \\
\hline P3-1 & 21912 & $14: 06$ & 27.2 & 7.69 & 0.0616 & 1948 & 0.13 & 0.034 & 1.351 & 0.072 & 0.293 & 0.015 & 2.546 & 3092 & 0.29 \\
\hline P3-1 & 51612 & $14: 46$ & 27.1 & 7.67 & 0.0544 & 2528 & 0.129 & 0.035 & 1.438 & 0.07 & 0.512 & 0.016 & 2.494 & 3160 & 0.285 \\
\hline P3-1 & 51812 & $7: 17$ & 27 & 7.54 & $\ldots$ & 2221 & 0.124 & 0.035 & 1.4 & 0.07 & 0.594 & 0.015 & 2.373 & 4058 & 0.122 \\
\hline P3-1 & 51812 & $9: 19$ & 27 & 7.67 & $\ldots$ & 1991 & 0.124 & 0.035 & 1.468 & 0.073 & 0.524 & 0.015 & 2.549 & 3220 & 0.3 \\
\hline P3-1 & 51712 & $14: 54$ & 27.1 & 7.6 & 0.0576 & 2343 & 0.137 & 0.036 & 1.442 & 0.077 & 0.677 & 0.016 & 2.31 & 3443 & 0.184 \\
\hline P3-1 & 91312 & $10: 11$ & 27.1 & 7.75 & 0.0662 & 745 & 0.13 & 0.033 & 1.152 & 0.062 & 0.112 & 0.014 & 2.416 & 2570 & 0.263 \\
\hline P3-1 & 91312 & $14: 45$ & 26.8 & 7.79 & 0.0721 & 816 & 0.132 & 0.033 & 1.18 & 0.062 & 0.118 & 0.014 & 2.41 & 2325 & 0.307 \\
\hline P3-1 & 120912 & $9: 23$ & 27.4 & 7.85 & 0.0576 & 1784 & 0.139 & 0.034 & 1.472 & 0.071 & 0.541 & 0.013 & 2.445 & 2055 & 0.47 \\
\hline P3-1 & 121012 & $14: 14$ & 27.1 & 7.9 & 0.0563 & 3384 & 0.131 & 0.035 & 1.457 & 0.06 & 0.524 & 0.014 & 2.525 & 1882 & 0.525 \\
\hline P3-2 & 121511 & $\ldots$ & 27.3 & 7.7 & 0.0113 & 2618 & 0.14 & 0.035 & 1.435 & 0.065 & 0.37 & 0.015 & 2.489 & 2953 & 0.316 \\
\hline P3-2 & 22012 & $14: 23$ & 27.1 & 7.76 & 0.0094 & 1277 & 0.132 & 0.033 & 1.201 & 0.074 & 0.344 & 0.016 & 2.072 & 2156 & 0.225 \\
\hline P3-2 & 51712 & $15: 27$ & 27.3 & 7.76 & $\ldots$ & 2665 & 0.13 & 0.034 & 1.354 & 0.071 & 0.471 & 0.015 & 2.332 & 2418 & 0.326 \\
\hline P3-2 & 91312 & $9: 36$ & 27.2 & 7.81 & 0.0122 & 705 & 0.136 & 0.034 & 1.134 & 0.177 & $\ldots$ & 0.013 & 2.358 & 2190 & 0.308 \\
\hline P3-2 & 121012 & $11: 24$ & 27 & 7.8 & $\ldots$ & 3051 & 0.135 & 0.034 & 1.557 & 0.063 & 0.21 & 0.013 & 2.887 & 2691 & 0.506 \\
\hline
\end{tabular}

Notes:

Analytical errors are $\pm 0.1^{\circ} \mathrm{C}$ for temperature; \pm 0.01 for $\mathrm{pH} ; \pm 4 \%$ for drip rate; and $\pm 3 \%$ for $\mathrm{pCO}_{2}$-air.

Analytical errors of concentrations are less than $1 \%$ for $\mathrm{Ca}^{2+}, \mathrm{NO}_{3}{ }^{-}, \mathrm{SO}_{4}{ }^{2-;}, 3 \%$ for $\mathrm{Na}^{+}, \mathrm{Mg}^{2+} ; 12 \%$ for $\mathrm{Cl}^{-}$; and $1 \%$ for $\mathrm{HCO}_{3}$

Figure 7. Relationships between air temperature, precipitation, and $p \mathrm{CO}_{2}$-air on February 19, 2012 (A) and February 20, 2012 (B). After heavy rainfall, outside air temperature suddenly decreased and cave-airflow direction was reversed near the entrance. Then, outside air with low $\mathrm{pCO}_{2}$-air was flowed into the cave and $\mathrm{pCO}_{2}$-air dramatically decreased.
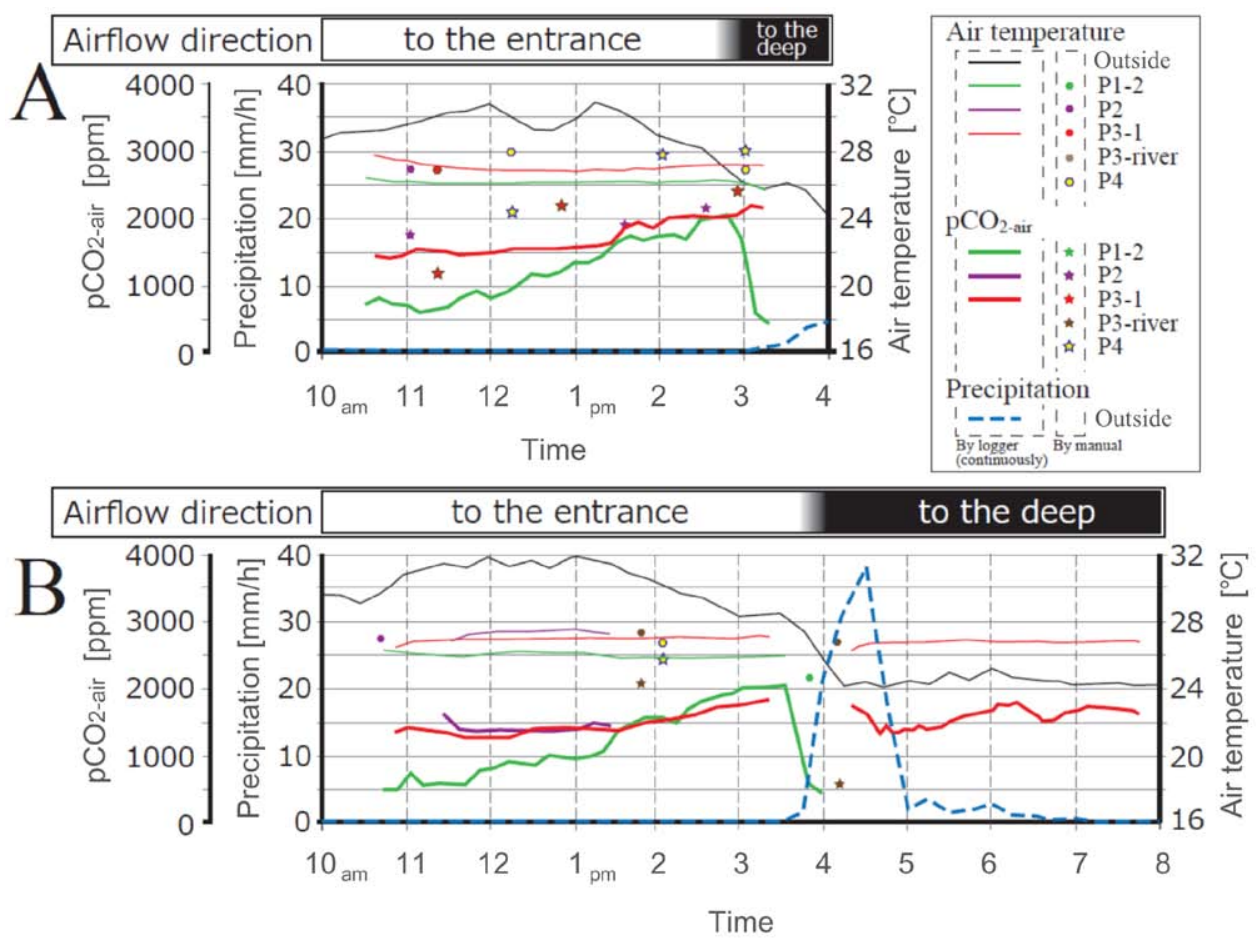
Air temperature: According to Baker et al. (1998) and Genty et al. (2001), stalagmite growth rate correlates positively with cave air temperature. In this cave, however, air temperature is almost constant throughout the year (Fig. 3), suggesting that cave air temperature has no influence on stalagmite growth.

Drip rate: According to Fairchild and Baker (2012), Dreybrodt and Franke (1987) show that stalagmite growth rate correlates positively with drip rate. On every sampling site of Petruk Cave, drip rates are almost constant throughout the year (Fig. 3), and there are changes on stalagmite growth rate throughout the year (Fig. 9), suggesting that drip rate is not the main influencing factor.

$\left[\mathrm{Ca}^{2+}\right]$ : Baker et al. (1998) reports that $\left[\mathrm{Ca}^{2+}\right]$ of drip water has a positive correlation with stalagmite growth rate. Assuming it to be true, $\left[\mathrm{Ca}^{2+}\right.$ of May and September 2012 should be higher than other seasons, because the growth rate is higher during this time (Fig. 9). However, this was not observed (Fig. 8), suggesting that [Ca ${ }^{2+}$ is not the main factor of stalagmite growth in this cave.

$\mathrm{pCO}_{2}$-air: After the cave monitoring of Spötl et al. (2005), $\mathrm{pCO}_{2}$-air has attracted attention as a key factor to control stalagmite growth (e.g., Spötl et al., 2005; Banner et al., 2007; Baldini et al., 2008). Comparing $p \mathrm{CO}_{2}$-air of this cave with stalagmite growth (Fig. 5 and Fig. 9), there is the relationship that stalagmite growth rate is high (low) when $p \mathrm{CO}_{2}$ air is low (high) during dry (rainy) season. This evidence suggests that $p \mathrm{CO}_{2}$-air controls stalagmite growth in this cave, a result similar to previous studies in mid latitudes (cen-
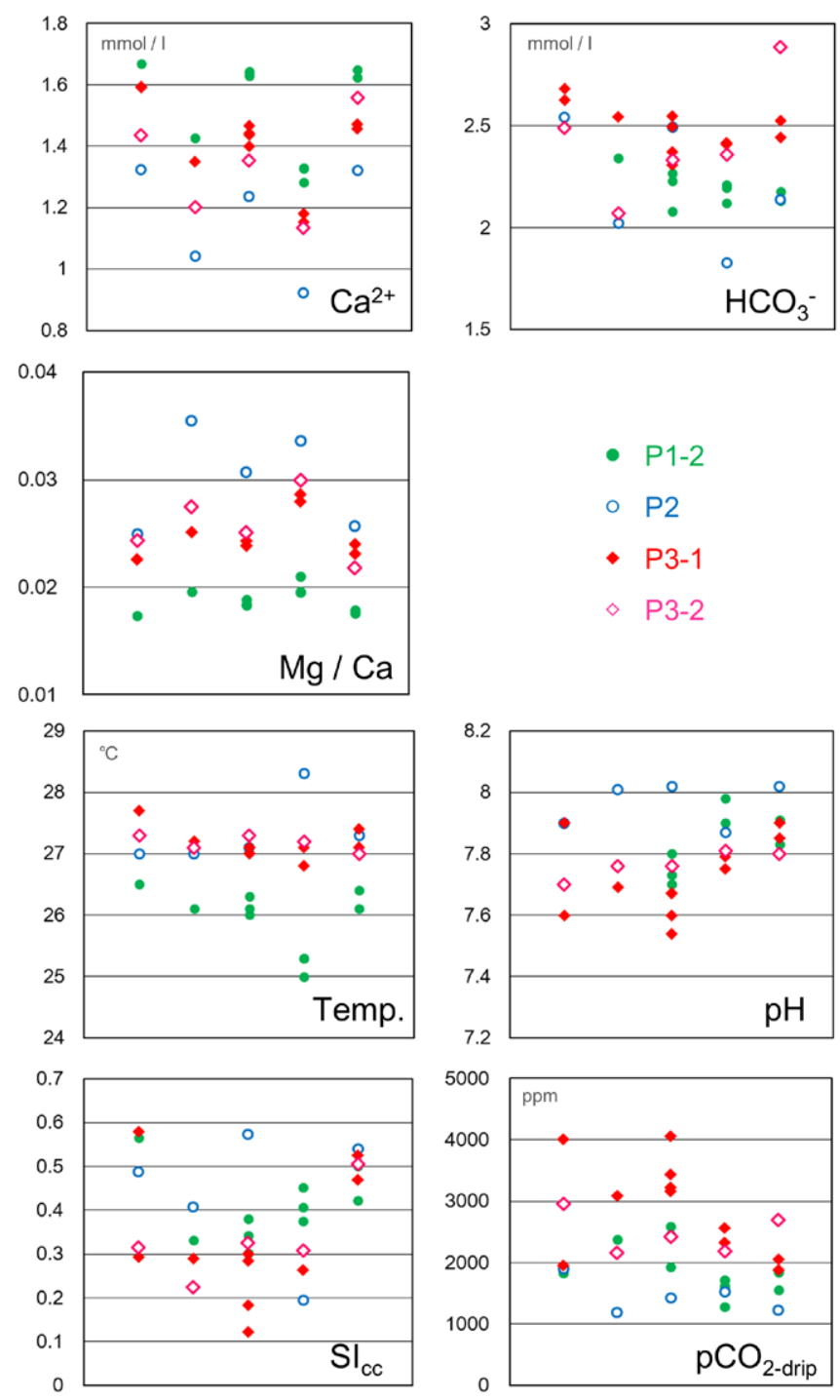

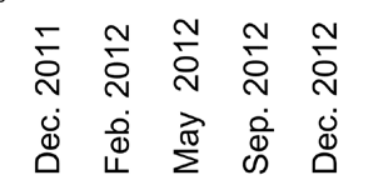

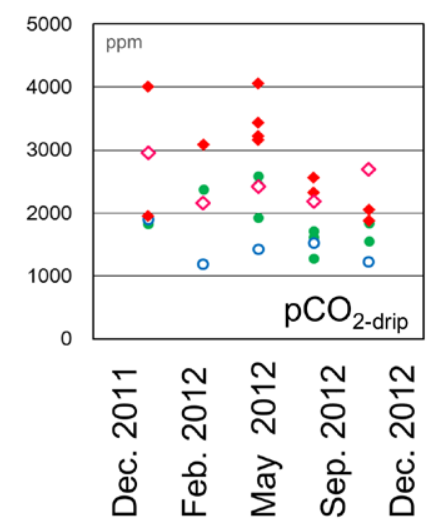

Figure 8. Chemical compositions of drip-water samples. tral Texas, USA; Banner et al., 2007). Note that this is a first report that dramatic $p \mathrm{CO}_{2}$-air reduction occurs during the dry season in a tropical cave and controls stalagmite growth. According to Banner et al. (2007), outside air temperature of central Texas has a large seasonal variation, and $p \mathrm{CO}_{2}$-air reduction occurs during winter months due to active cave ventilation. On the other hand, outside air temperature of our study area is almost constant through the year, and precipitation has a distinctive seasonal cycle (Fig. 2). Even on such region of the tropics, it is worth noting that the dramatic $\mathrm{pCO}_{2}$-air reduction occurs during the dry season.

\section{Possible causes of $p \mathrm{CO}_{2}$-air fluctuation}

Because $\mathrm{pCO}_{2}$-air is the main factor controlling stalagmite growth in Petruk Cave as described above, we discuss the mechanism of $p \mathrm{CO}_{2}$-air fluctuation. The monitoring results show that $p \mathrm{CO}_{2}$-air fluctuations are divided into seasonal fluctuations (Fig. 5) and daily fluctuations (Fig. 6; Fig. 7).

Seasonal fluctuation of $\mathrm{pCO}_{2}$-air: Daily averages of $\mathrm{pCO}_{2}$-air are 400 to $800 \mathrm{ppm}$ for September 2012, but 900 to $3500 \mathrm{ppm}$ during the rainy seasons in May 2012 and December 2012 (Fig. 5). Seasonal fluctuation of $\mathrm{pCO}_{2}^{-}$

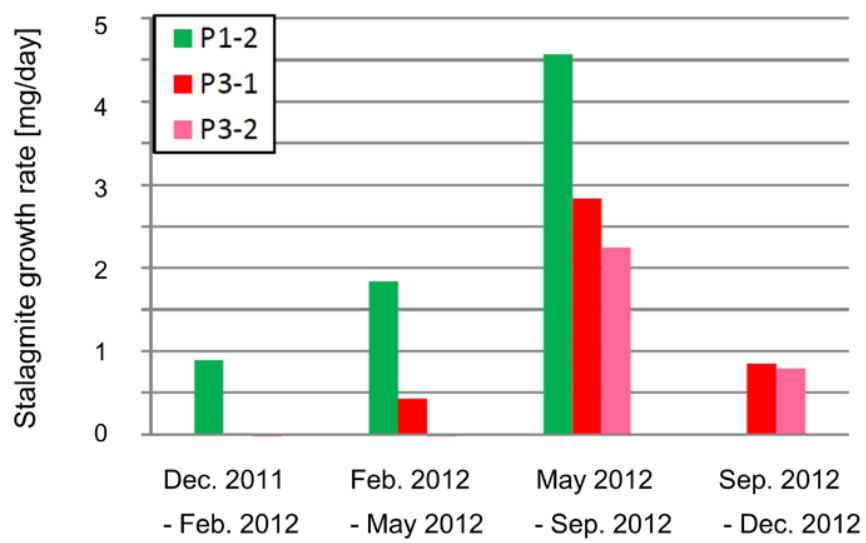

Figure 9. Stalagmite growth rates calculated by the weight of stalagmite farming on glass plates. Growth rates were higher during the dry season from May 2012 to September 2012 at all stations. 
air observed in this study is typical, as in previous studies (e.g., 400 to 1400 ppm in Austria, Spötl et al., $2005 ; 500$ to 8000 (30000 in extreme case) ppm in central Texas, Banner et al, 2007; 500 to 8000 ppm in Gibraltar, Mattey et al., 2010). Moreover, our seasonal fluctuation of $\mathrm{pCO}_{2}$-air is similar to that of Ridley et al. (2015) although the values they observed in Belize are lower than those of this study. The summer is characterized by higher mean $\mathrm{pCO}_{2}$-air $(-500 \mathrm{ppm})$ and high temporal variability, whereas winter has lower $\mathrm{pCO}_{2}$-air $(420 \mathrm{ppm})$ and displays lower temporal variability. Consequently, summer and winter in Belize correspond to wet and dry season in this study, respectively. According to Spötl et al. (2005), $\mathrm{pCO}_{2}$-air variation is driven by cave ventilation or $\mathrm{CO}_{2}$ production in the soil zone. In the case of Belize, the change of airflow direction from inflow to outflow appear mainly due to thermally induced inside-outside air density differences (Ridley et al., 2015). However, in Petruk Cave, airflow direction is almost constant throughout the year, as shown in Figure 4, because seasonal variation of outside air temperature is much lower (Fig. 2). On the other hand, $\mathrm{CO}_{2}$ productivity in the soil zone is assumed to have a seasonal variation due to rainy and dry season, similarly to the case of Thailand (Hashimoto et al., 2004). Accordingly, seasonal $\mathrm{pCO}_{2}$-air fluctuation and stalagmite growth are because in the rainy season, the rainfall amount enhances plant activity that leads to an increase of $\mathrm{CO}_{2}$ productivity in the soil zone, and therefore, higher $\mathrm{pCO}_{2}$-air that reduces stalagmite growth. During the dry season, little rainfall results in declines in the plant activity that lead to a reduction of $\mathrm{CO}_{2}$ productivity in the soil zone, and therefore, lower $p \mathrm{CO}_{2}$-air, resulting in increased stalagmite growth.

Daily fluctuation of $p \mathrm{CO}_{2}$-air: $p \mathrm{CO}_{2}$-air reaches a minimum around 6 a.m. and a maximum around 2 to 4 p.m. (Fig. 6; Fig. 7). Air temperature inside the cave remains constant throughout the year, and outside air temperature reaches a minimum around 6 a.m. and a maximum around $1 \mathrm{p} . \mathrm{m}$. This daily fluctuation of $p \mathrm{CO}_{2}$-air is similar to that observed in Belize during summer (Ridley et al., 2015). As Ridley and his colleagues pointed out, daily $p \mathrm{CO}_{2}$-air fluctuation observed in this study is also likely to be driven by the cave ventilation arising from the difference of air temperature between the outside and inside the cave or $\mathrm{CO}_{2}$ productivity of soil zone. In order to understand exactly the detailed mechanism of daily pCO2-air fluctuation, it is important for future studies to examine the cave ventilation at night and $\mathrm{CO}_{2}$ productivity of soil zone. It is also noteworthy that dynamic $\mathrm{pCO}_{2}$-air reduction was observed after heavy rain in February 2012 (Fig. 7). This is likely to have been caused by cave ventilation change driven by the sudden drop of outside air temperature due to a downburst during severe rain (Fig. 7).

\section{Conclusions}

In this study, stalagmite growth rate and environmental parameters were monitored in Petruk Cave from October 2011 to December 2012. We compared stalagmite growth rate with the environmental parameters, air temperature, drip rate, $\left[\mathrm{Ca}^{2+}\right]$, and $p \mathrm{CO}_{2}$-air. As a result, there is the relationship that stalagmite growth rate is fast (slow) when $p \mathrm{CO}_{2}$-air is low (high) during dry (rainy) season, suggesting that $\mathrm{pCO}_{2}$-air controls stalagmite growth.

The monitoring results show that $p \mathrm{CO}_{2}$-air fluctuation is divided into seasonal fluctuation and daily fluctuation. For the seasonal type, dramatic $\mathrm{pCO}_{2}$-air reduction during the dry season is likely result from a decline of plant activity due to little rainfall. Daily $\mathrm{pCO}_{2}$-air reached a minimum around $6 \mathrm{a}$.m. and a maximum around 2 to $4 \mathrm{p}$.m., although it is not obvious whether plant activity or cave ventilation arising from the difference of air temperature between the outside and the inside cave. Dynamic $p \mathrm{CO}_{2}$-air reduction was also observed after a heavy, intense rain, suggesting that heavy rainfall of short duration is also one factor that controls cave ventilation and $\mathrm{pCO}_{2}$-air.

\section{Acknowledgements}

We are indebted to Prof. S. Yoden and Prof. K. Takemura (Kyoto Univ., Japan) for generous support to this study. We are very grateful to Mr. T. Mishima (Kyoto Univ., Japan) and Ms. I.Y. Purnamasari (ITB, Indonesia) for their technical support. This study was supported by Program for Next Generation World-Leading Researches (NEXT Program; GR063).

\section{References}

Baker, A., Genty, D., Dreybrodt, W., Barnes, W.L., Mockler, N.J., and Grapes J., 1998, Testing theoretically predicted stalagmite growth rates with recent annually laminated samples: implications for past stalagmite deposition: Geochimica et Cosmochimica Acta, v. 62, 393-404. https:// doi.org/10.1016/S0016-7037(97)00343-8.

Baldini, J.U.L., McDermott, F., Hoffmann, D.L., Richards, D.A., and Clipson, N., 2008, Very high-frequency and seasonal cave atmosphere $P_{\text {co2 }}$ variability: Implications for stalagmite growth and oxygen isotope-based paleoclimate records: Earth and Planetary Science Letters, v. 272, 118-129. https://doi.org/10.1016/j.epsl.2008.04.031.

Banner, J.L., Guilfoyle, A., James, E.W., Stern, L.A., and Musgrove, M., 2007, Seasonal variations in modern speleothem calcite growth in central Texas, U.S.A.: Journal of Sedimentary Research, v. 77, 615-622. https://doi.org/10.2110/jsr.2007.065.

Boch, R., Spötl, C., and Frisia, S., 2011, Origin and palaeoenvironmental significance of lamination in stalagmites from Katerloch Cave, Austria: Sedimentology, v. 58, 508-531. https://doi.org/10.1111/j.1365-3091.2010.01173.x.

Brahmantyo, B., Sampurno, Puradimaja, D.J., and Harsolumakso, A.H., 2006, Geological controls on the distribution of resurgences in Karangbolong karst mountain, Kebumen, central Java: Proceeding Persidangan Geosains UKM-ITB 2006.

Dreybrodt, W., and Franke, H.W., 1987, Wachstumsgeschwindigkeiten und durchmesser von kerzenstalagmiten: Die Höhle, v. 38, 1-6. 
Fairchild, I.J., and Baker, A, 2012, Speleothem Science: from Process to Past Environments: London, John Wiley \& Sons Ltd, 432 p.

Fairchild, I.J., Borsato, A., Tooth A.F., Frisia, S., Hawkesworth, C.J., Huang, Yiming, McDermott, F., and Spiro, B., 2000, Controls on trace element $(\mathrm{Sr}-\mathrm{Mg}$ ) compositions of carbonate cave waters: implications for speleothem climatic records: Chemical Geology, v. 166, 255-269. https://doi.org/10.1016/S0009-2541(99)00216-8.

Fairchild, I.J., Smith, C.L., Baker, A., Fuller, L., Spötl, C., Mattey, D., McDermott, F., and E.I.M.F., 2006, Modification and preservation of environmental signals in speleothems: Earth-Science Reviews, v. 75, 105-153. https://doi.org/10.1016/j.earscirev.2005.08.003.

Genty, D., Baker, A., and Vokal, B., 2001, Intra- and inter-annual growth rate of modern stalagmites: Chemical Geology, v. 176, 191-212. https:// doi.org/10.1016/S0009-2541(00)00399-5.

Hashimoto, S., Tanaka, N., Suzuki, M., Inoue, A., Takizawa, H., Kosaka, I., Tanaka, K., Tantasirin, C., and Tangtham, N., 2004, Soil respiration and soil $\mathrm{CO}_{2}$ concentration in a tropical forest, Thailand: Journal of Forest Research, v. 9, 75-79. https://doi.org/10.1007/s10310-003-0046-y.

Mattey, D.P., Fairchild I.J., Atkinson, T.C., Latin, J.-P., Ainsworth M., and Durell, R., 2010, Seasonal microclimate control of calcite fabrics, stable isotopes and trace elements in modern speleothem from St Michaels Cave, Gibraltar: in Pedley, H.M., and Rogerson, M., eds.,Tufas and Speleothems: Unravelling the Microbial and Physical Controls, Geological Society, London, Special Publications, v. 336, 323-344. https://doi. org/10.1144/SP336.17.

Mishima, T., Ohsawa, S., Yamada, M., and Kitaoka, K., 2009, A new method for determination of bicarbonate ion in a small amount of environmental water samples: Journal of Japanese Association of Hydrological Sciences, v. 38, no. 4, 157-168. in Japanese. http://doi.org/10.4145/ jahs.38.157.

Polyak, V.J., and Asmerom, Y., 2001, Late Holocene climate and cultural changes in the southwestern United States: Science, v. $294,148-151$. http://doi.org/10.1126/science.1062771.

Proctor, C.J., Baker, A., Barnes, W.L., and Gilmour, M.A., 2000, A thousand year speleothem proxy record of North Atlantic climate from Scotland: Climate Dynamics, v. 16, 815-820. https://doi.org/10.1007/s003820000077.

Ridley, H.E., Baldini, J.U.L., Prufer, K.M., Walczak, I.W., and Breitenbach, S.F.M, 2015, High-resolution monitoring of Yok Balum Cave, Belize: An investigation of seasonal ventilation regimes and the atmospheric and drip-flow response to a local earthquake: Journal of cave and Karst Studies, v. 77, 183-199. http://dx.doi.org/10.4311/2014ES0117.

Sondag, F., van Ruymbeke, M., Soubiès, F., Santos, R., Somerhausen, A., Seidel, A., and Boggiani, P., 2003, Monitoring present day climatic conditions in tropical caves using an Environmental Data Acquisition System (EDAS): Journal of Hydrology, v. 273, 103-118. https://doi. org/10.1016/S0022-1694(02)00362-1.

Spötl, C., Fairchild, I.J., and Tooth, A.F., 2005, Cave air control on dripwater geochemistry, Obir Caves (Austria): Implications for speleothem deposition in dynamically ventilated caves: Geochimica et Cosmochimica Acta, v. 69, 2451-2468. https://doi.org/10.1016/j.gca.2004.12.009.

Tremaine, D.M., Froelich, P.N., and Wang, Yang, 2011, Speleothem calcite farmed in situ: Modern calibration of $\delta^{18} \mathrm{O}$ and $\delta^{13} \mathrm{C}$ paleoclimate proxies in a continuously-monitored natural cave system: Geochimica et Cosmochimica Acta, v. 75, 4929-4950. https://doi.org/10.1016/ j.gca.2011.06.005.

Wang, Y.J., Cheng, H., Edwards, R.L., An, Z.S., Wu, J.Y., Shen, C.-C., Dorale, J.A., and 2001, A high-resolution absolute-dated late Pleistocene monsoon record from Hulu Cave, China: Science, v. 294, 2345-2348. https://doi.org/10.1126/science.1064618.

Wang Yongjin, Cheng Hai, Edwards, R.L., Kong Xinggong, Shao Xiaohua, Chen Shitao, Wu Jiangyin, Jiang Xiouyang, Wang Xianfang, and An Zhisheng, 2008, Millennial- and orbital-scale changes in the East Asian monsoon over the past 224,000 years: Nature, v. 451, 1090-1093. https://doi.org/10.1038/nature06692.

Wong, C. I., Banner, J.L., and Musgrove, M., 2011, Seasonal dripwater Mg/Ca and Sr/Ca variations driven by cave ventilation: Implications for and modeling of speleothem paleoclimate records. Geochimica et Cosmochimica Acta, v. 75, 3514-3529. https://doi.org/10.1016/ j.gca.2011.03.025 